\title{
The Role of Accounting Information Systems in Activating the Role of the Responsibility in the Jordanian Industrial Companies
}

\author{
Mohammad Abdallah Fayad Altawalbeh, Firas Na’el Rawhi Hashem, Khalid Ali Ahmad Alduneibat \\ Tafilah Technical University, Jordan
}

\begin{abstract}
The study aims at examining the role of accounting information systems in activating the role of the responsibility accounting in the Jordanian industrial companies. The study population has consisted of accounting managers working in the Jordanian industrial companies, where a convenience sample of 50 managers has been taken and questionnaires have been distributed for them and then these questionnaires have been collected. The study has found that the attitudes of study sample have been positive toward the role of accounting information systems in activating the role of the responsibility accounting in the Jordanian industrial companies. The study has also found that there is a role for accounting information systems in activating the role of the responsibility accounting in the Jordanian industrial companies. The study also found that the role of accounting information systems in activating the role of the responsibility accounting in the Jordanian industrial companies does not vary depending on the educational qualification of employees. In addition, the role of accounting information systems in activating the role of responsibility accounting in the Jordanian industrial companies varies depending on the practical experience of the employee. The study has made several recommendations, including: focusing attention on the disclosure of social activities in industrial companies, in addition to focusing on the development of equipment used in information systems at the company.
\end{abstract}

Keywords: accounting information system, responsibility accounting, information system

\section{Introduction}

Today, man lives in an environment that is very rich with data and information; some believe that the flow of information is important to the life or the health of the enterprise business just as those represented by the force of blood to the human health and life. Perhaps the increasing numbers of consumers and the diversity of their needs and desires and the number of competitors and therefore the need for better utilization of available resources exploitation and taking the rapid right decision based on accurate, comprehensive and correct information available in a timely manner, have increased the importance of management information systems (Al Qashi, 2003).

Also, all organizations are seeking to increase their profitability and return on investment, and governments are concerned with the achievements of the companies because they are the wheel of development and contribute to the balance of payments. It is worth mentioning that the use of information is not restricted to

Mohammad Abdallah Fayad Altawalbeh, Lecturer, Accounting Department, Tafilah Technical University. Email: Tawalbeh74@yahoo.com.

Firas Na’el Rawhi Hashem, Lecturer, Accounting Department, Tafilah Technical University.

Khalid Ali Ahmad Alduneibat, Lecturer, Accounting Department, Tafilah Technical University. 
a particular manager or a department, but all administrative levels need to use information, which increases the importance of management information systems in the organization. Accounting information is known as a system for collecting and recording, storing, and processing data to produce information for the decision makers (Romney \& Steinbart, 2009).

The accounting information systems are one of the important systems in the economic union; organizations vary among themselves in terms of the application of the accounting systems of information and the extent of the awareness of their importance. For them, to face many factors may affect one way or another in the extent of the application of the accounting information systems (Granlund, 2011).

The social responsibility of business organizations is the center of attention in developed societies, especially in light of heightened competition between the companies and the existence of consumer protection associations, labor unions and government legislation which call companies for incurring their social responsibility, which made these communities go a long way ahead in terms of studies, debate, and practices. The accounting information system is a set of sub-systems used in the compilation and tabulation and processing, analysis and communicating appropriate information to make decisions to internal management and external parties, one of the sub-systems of the information in the institution where he only cares about economic events that can be expressed in quantitative and cash (Iskandar, 2015).

\section{Literature Review}

Accounting information systems have been widely adopted by organizations within both the public and private sectors (Rom \& Rohde, 2007). Accounting information system in companies covers both structured and unstructured financial and non-financial information for decision-making, management control, and performance management (Granlund, 2011).

The accounting information system is one of the management information system components (Scott, 1986, p. 66). Although many researchers agree on the nature of the relationship mentioned between the two systems, and some believe that the accounting information system is the basis and the management information system is part of it, others argue that the accounting information system is an independent system for the management information system, however, the two systems overlap with each other (Alikhani, Ahmadi, \& Mehravar, 2013).

The researchers review a large number of previous studies, which were divided into two kinds, the first one is practical and empirical, and the second one is theoretical. These studies are carried out in different environments, countries, and industries. The studies showed that the accounting information system is constantly evolving, and it became necessary for the different processes and activities within companies, and this requires the organizations to apply it and use.

The literature shows that accounting information system is a basic resource for organizations and institutions in the private and public sectors, to deal with the current circumstances characterized by rapid change and the intensification of competition, not only at the local level, but also at the international level. The literature of accounting information systems has a wide position of importance in all areas, where information systems have evolved at a rapid pace and numerous applications at all administrative levels. The information checks many advantages through which they provide important information for all communities of users of information. Esmeray (2016) investigated the relationship between the use of the accounting information systems by the small- and medium-sized enterprises in Turkey and performance indicators of studied furniture firms. The study 
found that there is a positive and statistically significant relation between the use of accounting information systems and educational status of managers in furniture firms, and as the number of employees increases, the use of accounting information systems also increases. The study also reported a positive relation between the use of accounting information systems and growth of some performance indicators such as sale, customer, and revenue. It was concluded that there is a positive and statistically significant relation between the use of accounting information systems and educational status of directors in furniture firms. The results show that the use of information systems becomes more common as a result of an increasing advanced level of education.

Also, Nwinee, Akpos, Vincent, and Ibinabo (2016) examined the impact of accounting information system on the SMEs performance in Nigeria. Management efficiency and cost control was used by the study to proxy organizational effectiveness. It is found that accounting information system enhances management efficiency and cost control by supporting rational operational decisions. The study also found that accounting information system has significant impact on the effectiveness of small and medium scale enterprises in Nigeria. Patel (2015) investigated the importance of accounting information in making decisions by studying the effect of accounting information systems on profitability level of organization. The study reported that, "Accounting information systems is a part of company's information systems this helps in facilitating decision making within organizations and can be modified to an organization's environment, structure and requirements of task" (Patel, 2015, p. 72).

In addition, Ware (2015) examined the relationship between computerized accounting system and effective means of keeping accounting records of Ga Rural Bank in Yamane. The study reported that, "There is the need for businesses, particularly rural banks to adopt a Computerized Accounting System” (Ware, 2015, p. 111). Whereas Samuel (2013) investigated the impact of accounting information system on organizational effectiveness of automobile companies in Kenya. The study reported that accounting information systems are an important mechanism for organizations' effective management, decision-making, and controlling activities. The study reported that accounting information systems on a timely basis are critical not only to the production of quality accounting information but also to the communication of that information to the decision makers in selected automobile companies.

\section{The Problem of the Study}

Despite the importance of the subject of accounting information systems and its role in activating the role of responsibility accounting in the Jordanian industrial companies, there was a lack of researches and studies in Jordan dealing with this subject. As well as the fact that the success and efficiency of the decision-making process depends to a large extent on the degree of availability of information and that the existence of an efficient system of information has become a basic requirement for survival and not only as a means to improve performance.

\section{Questions of the Study}

The problem of the study lies in the answer to the following questions:

(1) What is the role of accounting information systems in activating the role of the responsibility accounting in the Jordanian industrial companies?

(2) Are there statistically significant differences for the role of accounting information systems in activating the role of the responsibility accounting in the Jordanian industrial companies attributed to the educational qualification and experience of the employee? 


\section{Hypotheses of the Study}

The study hypothesizes the following:

(1) H0: There is no role for accounting information systems in activating the role of the responsibility accounting in the Jordanian industrial companies.

(2) H0: There are no statistically significant differences in the role of accounting information systems in activating the role of the responsibility accounting in the Jordanian industrial companies attributed to the educational qualification and experience of the employee.

\section{Population and Sample of the Study}

The study population has consisted of accounting managers working in the Jordanian industrial companies, where a convenience sample of 50 managers has been taken and questionnaires have been distributed for them and then these questionnaires have been collected.

\section{Methods of Data Collection}

Two types of sources to gather information have been adopted, namely:

(1) Secondary sources: It means the books and references and previous studies on the subject of the study.

(2) Primary sources: Preparation and design of the study questionnaire have been adopted.

\section{The Characteristics of Study Sample}

\section{Gender}

As seen in Table 1, we note that $94 \%$ of the respondents are male and the rest are female, which means that the highest percentage of accounting managers is males.

Table 1

The Respondents' Distribution by Gender

\begin{tabular}{lcc}
\hline Gender & Frequency & Percentage (\%) \\
\hline Male & 47 & 94.0 \\
Female & 3 & 6.0 \\
Total & 50 & 100 \\
\hline
\end{tabular}

\section{Educational Qualifications}

We note that $92 \%$ of the respondents are bachelor's degree holders, and the rest are postgraduates (see Table 2).

Table 2

The Respondents'Distribution by Educational Qualifications

\begin{tabular}{lcc}
\hline Educational qualifications & Frequency & Percentage (\%) \\
\hline Diploma & - & - \\
Bachelor & 46 & 92.0 \\
Postgraduate & 4 & 8.0 \\
Total & 50 & 100 \\
\hline
\end{tabular}




\section{Experience in the Company}

We note that $32 \%$ of the respondents have experience that is less than one year, and $36 \%$ of the respondents have experience ranging between 1 and 5 years, and the rest have experience that is more than five years (see Table 3).

Table 3

The Respondents'Distribution by Experience in the Company

\begin{tabular}{lcc}
\hline Experience in the company & Frequency & Percentage (\%) \\
\hline Less than 1 & 16 & 32.0 \\
$1-5$ & 18 & 36.0 \\
$5-10$ & 9 & 18.0 \\
More than 10 & 7 & 14.0 \\
Total & 50 & 100 \\
\hline
\end{tabular}

\section{Results of the Study}

The arithmetic mean and standard deviation have been extracted to describe the sample answers about the paragraphs below (see Table 4).

Table 4

Mean and Standard Deviation for the Questions

\begin{tabular}{|c|c|c|c|}
\hline Question & Paragraph & Mean & Std. dev. \\
\hline 1 & The accounting disclosure on the social activities of the company is done. & 4.1600 & 1.05676 \\
\hline 2 & Management uses the responsibility accounting as an internal tool for reports in the company. & 4.6600 & 0.51942 \\
\hline 3 & The company is responsible as an economic unit for various social aspects. & 4.8200 & 0.38809 \\
\hline 4 & The company engages and interacts with various social activities. & 4.6400 & 0.59796 \\
\hline 5 & The company provides suitable working conditions for workers. & 4.3600 & 0.74942 \\
\hline 6 & The disparity in performance levels in the company is taken into account. & 4.4400 & 0.70450 \\
\hline 7 & $\begin{array}{l}\text { The financial statements of the company include special explanations about its social } \\
\text { performance. }\end{array}$ & 4.6200 & 0.60238 \\
\hline 8 & The company is involved in the environmental protection programs. & 4.4200 & 0.70247 \\
\hline 9 & $\begin{array}{l}\text { There is in the company accounting system that fulfills the purposes of disclosure of the social } \\
\text { performance. }\end{array}$ & 4.5800 & 0.70247 \\
\hline 10 & $\begin{array}{l}\text { The company makes periodic review of the methods of disclosure of its social performance in } \\
\text { order to reach the optimal method for that disclosure. }\end{array}$ & 4.6000 & 0.78246 \\
\hline 11 & $\begin{array}{l}\text { The company discloses its social performance by descriptive method within the annual } \\
\text { financial reports. }\end{array}$ & 4.5600 & 0.73290 \\
\hline 12 & $\begin{array}{l}\text { The company discloses its social performance in quantitative method within the annual } \\
\text { financial reports. }\end{array}$ & 3.9600 & 0.94675 \\
\hline 13 & $\begin{array}{l}\text { Observations of the external auditor are respected in order to develop the method of disclosure } \\
\text { of social performance. }\end{array}$ & 3.9000 & 0.73540 \\
\hline 14 & The company gives priority to the local community when appointing its employees. & 4.2400 & 0.68690 \\
\hline 15 & $\begin{array}{l}\text { The company contributes to the training of the local community people in order to equip them } \\
\text { with the skills and multiple careers. }\end{array}$ & 4.1000 & 0.70711 \\
\hline 16 & $\begin{array}{l}\text { The software and hardware used in accounting information system are the best and the latest of } \\
\text { what is available locally. }\end{array}$ & 3.88 & 0.982 \\
\hline 17 & $\begin{array}{l}\text { The software and hardware used in accounting information system are suited to the operating } \\
\text { requirements of the facility. }\end{array}$ & 4.2000 & 0.72843 \\
\hline 18 & $\begin{array}{l}\text { It is easy to deal with the hardware and does not require a high degree of specialization or level } \\
\text { of education. }\end{array}$ & 4.2800 & 0.70102 \\
\hline 19 & The devices used achieve the desired goals of the accounting information system as appropriate. & 4.3200 & 0.79385 \\
\hline 20 & $\begin{array}{l}\text { The available input and output devices cover all the needs in order to take advantage of the } \\
\text { information system. }\end{array}$ & 4.3800 & 0.66670 \\
\hline
\end{tabular}


We note that the attitudes of sample are positive towards the paragraphs above because their arithmetic means are greater than the average of measurement tool (3).

\section{Reliability Test}

Test of Cronbach's alpha has been used to measure the stability of the measuring instrument as the value is $0.863 \%$, which is an excellent ratio as it is higher than the acceptable ratio of 60\% (Malhotra, 2004).

\section{Test Hypotheses}

\section{Testing of Hypothesis 1}

H0: There is no role for accounting information systems in activating the role of the responsibility accounting in the Jordanian industrial companies.

Simple regression is used to test the above hypothesis; it is found that the calculated value of $(F)$ is significant at the 0.05 level. This means that the null hypothesis is rejected, which means that there is a role for accounting information systems in activating the role of the responsibility accounting in the Jordanian industrial companies with moderate Pearson correlation of 0.50 (see Table 5).

Table 5

The Test of the First Hypothesis

\begin{tabular}{llllll}
\hline$T$ calculated & $T$ tabulated & $T$ sig. & The result of H0 & $r$ & $r^{2}$ \\
\hline 4.003 & 2.0096 & 0.000 & Rejected & 0.50 & 0.25 \\
\hline
\end{tabular}

\section{Testing of Hypothesis 2}

H0: The role of accounting information systems in activating the role of responsibility accounting in the Jordanian industrial companies does not vary depending on the educational qualification of the employee.

Table 6

The Test of the Second Hypothesis

\begin{tabular}{llll}
\hline$F$ calculated & $F$ tabulated & $F$ sig. & The result of H0 \\
\hline 0.115 & 3.28 & 0.891 & Accepted \\
\hline
\end{tabular}

One-way ANOVA test has been used. It is found that the value of $F$ calculated is 0.115 , which is not significant at the 0.05 level (see Table 6). This means that the null hypothesis is accepted, which means that the role of accounting information systems in activating the role of responsibility accounting in the Jordanian industrial companies does not vary depending on the educational qualification of the employee.

\section{Testing of Hypothesis 3}

H0: The role of accounting information systems in activating the role of responsibility accounting in the Jordanian industrial companies does not vary depending on the experience of the employee.

Table 7

The Test of the Third Hypothesis

\begin{tabular}{llll}
\hline$F$ calculated & $F$ tabulated & $F$ sig. & The result of H0 \\
\hline 3.609 & 2.31 & 0.006 & Rejected \\
\hline
\end{tabular}


One-way ANOVA test has been used. It is found that the value of $F$ calculated is 3.609 which is significant at the 0.05 level. This means that the null hypothesis is rejected, which means that the role of accounting information systems in activating the role of responsibility accounting in the Jordanian industrial companies varies depending on the experience of the employee (see Table 7).

\section{Results}

The testing results of the paper are as follows:

(1) There is a role for the accounting information systems in activating the role of the responsibility accounting in the Jordanian industrial companies;

(2) The role of accounting information systems in activating the role of responsibility accounting in the Jordanian industrial companies does not vary depending on the educational qualification of the employees;

(3) The role of accounting information systems in activating the role of responsibility accounting in the Jordanian industrial companies varies depending on the practical experience of employees.

\section{Recommendations}

Based on the study results, we recommend the following:

(1) To focus attention on the disclosure of social activities in industrial companies;

(2) To focus on the development of equipment used in information systems at the company;

(3) To train employees to harmonize accounting information systems and responsibility accounting;

(4) To focus attention on participating in environmental protection programs;

(5) To conduct other researches by applying on other economic sectors.

\section{References}

Al Qashi, Z. (2003). The effectiveness of accounting information systems to achieve safety and reliability in light of e-commerce (Ph.D. thesis, Amman Arab University for Graduate Studies, Jordan).

Alikhani, H., Ahmadi, N., \& Mehravar, M. (2013). Accounting information system versus management information system. European Online Journal of Natural and Social Sciences, 2(3), 359-366.

Esmeray, A. (2016). The impact of accounting information systems on firm performance: Empirical evidence in Turkish small and medium sized enterprises. International Review of Management and Marketing, 6(2), 233-236.

Granlund, M. (2011). Extending AIS research to management accounting and control issues: A research note. International Journal of Accounting Information Systems, 12(1), 3-19.

Iskandar, D. (2015). Analysis of factors affecting the success of the application of accounting information system. International Journal of Scientific \& Technology Research, 4(2), 155-162.

Malhotra, N. K. (2004). Marketing research. New Jersey, NJ: Prentice Hall.

Nwinee, K., Akpos, Y., Vincent, G., \& Ibinabo, T. (2016). Impact of accounting information system on organizational effectiveness: A study of selected small and medium scale enterprises in Woji, Portharcourt. International Journal for Research in Business, Management and Accounting, 2(1), 62-72.

Patel, S. (2015). Effects of accounting information system on organizational profitability. International Journal of Research and Analytical Reviews, 2(1), 72-76.

Rom, A., \& Rohde, C. (2007). Management accounting and integrated information systems: A literature review. International Journal of Accounting Information Systems, 8(1), 40-68.

Romney, M. B., \& Steinbart, P. J. (2009). Accounting information systems (11th ed.). New Jersey, NJ: Person Prentice Hall.

Samuel, N. (2013). Impact of accounting information systems on organizational effectiveness of automobile companies in Kenya (Master theses, University of Nairobi).

Scott, M. (1986). Principles of management information systems. New York, NY: McGraw-Hill Book Co..

Ware, E. (2015). Computerised accounting system an effective means of keeping accounting records in Ghanaian banks: A case study of the Ga Rural Bank. International Journal of Research in Business Studies and Management, 2(11), 111-141. 